\title{
1. Introduction to the Handbook on Intervention and Statebuilding: moving beyond the current orthodoxy
}

\author{
Nicolas Lemay-Hébert
}

There is a wide consensus among researchers and practitioners on the importance of state weakness or state collapse in contemporary world politics. After all, a number of issues are subsumed under the wide rubric of state collapse, including ethnic conflicts, refugee flows, governance issues or threats to human security. For the authors of the 2018 SIPRI Yearbook, one of the important issues was how criminal violence thrives in areas of a country in which central state control is absent, limited or corrupted (Smith 2018, p. 19; see also Chapter 27 by Lorraine Elliott in this volume for a focus on transnational crimes and statebuilding). The everyday challenges for citizens living in Syria, Yemen or Afghanistan are hard to ignore. In the face of these challenges, only a marginal cluster of authors argue for hardline non-interventionary policies (for an overview of this discussion subsumed under the "fresh start' approach, see Lemay-Hébert 2019). However, if there is a consensus on the importance of external assistance for states undergoing major crises, the exact nature of this external assistance - and the usefulness of specific types of interventions - is still widely debated.

The failure of past interventions - the 2003 Iraqi military intervention and consequent occupation being on everyone's mind - but also the lack of progress in Afghanistan since 1999, in Haiti since 2004, or in many African countries with a peacekeeping presence, has led to a new era of doubt in policy circles regarding the usefulness of interventions. After the certainties of the 1990s and early 2000s, marked by a modernistic logic of listing failed states, which legitimized subsequent top-down interventions following simple causation logics ('intervention A' responding to 'problem B' and leading to intended 'outcome C'), interveners are now familiar with complexity theories and (sometimes instinctively) understand the full reach of possible unintended outcomes for each intervention ('intervention A' is meant to respond to 'problem B' but can lead to a multiple set of outcomes - from C to $\mathrm{Z}$ - as well as potentially creating new problems; see also Chapter 2 by David Chandler in this volume). The experience of Iraq - where the military intervention led to years of chaos, insecurity, and the concomitant rise of Islamic State of Iraq and Syria (see Chapter 31 by Yasmin Chilmeran and Jacqui True in this volume for a discussion of peacebuilding in Iraq); the peacekeepers' introduction of cholera in Haiti - an illness which killed more than 10,000 people and infected 10 per cent of the population; and the multiple sexual scandals involving peacekeepers helped drive the point home that interventions are more likely to produce non-linear outcomes. Adaptability becomes the new motto for interveners, and small, targeted interventions have tended to replace the modern top-down interventions.

This Handbook starts from the premise that statebuilding is intractably linked to international interventions. For a start, we know that state fragility is linked to statebuilding interventions, both in theory and in practice (Lemay-Hébert 2020). Hence, state weakness 


\section{Handbook on intervention and statebuilding}

is understood to be 'corrected' or addressed through statebuilding interventions. But more generally, how one defines the state will have ramifications for how one conceptualizes, in turn, state fragility, statebuilding, and international interventions meant to build the peace that is supposed to follow. Through the modern - and quite mainstream - episteme, the state is understood to be a provider of public goods, and the key public good in a Weberian fashion is security provision. Max Weber's (1948, p. 78) definition of the state 'as a human community that successfully claims the monopoly of the legitimate use of physical force within a given territory' gained traction across various disciplines, and has contributed to cementing peace and conflict's disciplinary focus on security provision and state institutions (Lottholz and Lemay-Hébert 2016). What came to be known as the institutional approach to statebuilding (Lemay-Hébert 2009, 2013) has also been challenged by other approaches, bundled under the wide umbrella of 'social legitimacy' (Lemay-Hébert 2014). However, the institutional approach has contributed to solidifying, and to a certain extent continues to drive the practices of interventions and statebuilding. This Handbook, by and large, offers a number of alternative research avenues challenging the mainstream approaches to statebuilding, moving beyond the current orthodoxy.

\section{FROM STATEBUILDING TO STATE FORMATION, AND BACK AGAIN}

Statebuilding has long been considered through a narrow perspective as the (re)building of state institutions, but other approaches are possible. It all starts from the definition of the state that one adopts. As Anthony Giddens (1985, p. 17) observes, there are two implicit concepts behind the notion of state: it sometimes means an apparatus of government or power, or sometimes the overall social system subject to that government or power. Hence, whether one adopts a 'restrictive' or more comprehensive conception of the state will carry specific implications for the analysis of statebuilding. The two conceptions of the state - as government or as social system - can be associated with distinct sociological camps, each with their own sets of assumptions. In this regard, the neo-Weberian approach to statehood is the starting point for a number of analyses, having attained the status of orthodoxy in the mainstream social science literature, even if to a certain extent neo-Weberians fail to do justice to the complexity of Weber's sociology of the state (Lottholz and Lemay-Hébert 2016). State capacities to govern are deemed central to the institutionalist approach; states exist to deliver public goods which encompass a list of state institutions and functions.

Following the 'institutional approach', the state is equated with its institutions; state collapse is understood in terms of the collapse of state institutions, and, consequently, statebuilding implies their (re)construction. While being portrayed implicitly as consensual and apolitical, the institutional approach to statebuilding carries specific consequences for theories and methodologies in peace and conflict (Lemay-Hébert 2013). However, the main practical implication of the institutional approach directly connects intervention and statebuilding together: by depoliticizing the institutional processes of statebuilding, institutionalists legitimize international interventions, meant to supplement the 'lack of state capacity'. First, the restrictive focus on state capabilities allows one to identify failed or failing states according to institutional strength, providing the theoretical underpinnings for forecasting state failure. In this context, 'developed countries' of the West continue the practices of setting standards against which 
other states are inevitably measured. Second, the division between state structures and societal forces leads, very conveniently, to a distinction between state- and nationbuilding, so that it becomes possible to conceive of statebuilding operations being possible from the outside, without entering into the more politically contested terrain of nationbuilding (Lemay-Hébert 2009). In other words, from this perspective it becomes 'technically' possible to target institutions of a given state and strengthen state capabilities, without necessarily engaging with the much thornier and less 'technical' issue of how to improve the socio-political cohesion of an often deeply divided 'society'. Third and finally, a 'more is better' approach (Lemay-Hébert 2013) follows as a policy prescription - legitimizing intrusive, top-down interventions on the grounds that they are more efficient for institutional reconstruction. Within this world-view, 'the more intrusive the intervention is, the more successful the outcome would be' (Zuercher 2006, p. 2). This modernistic assumption has been shattered in recent years.

Based on the narrow definition of the state as institutions, one can jump to the conclusion that statebuilding 'appears to be failed by design' (Richmond 2014, p. 11). However, that would be overseeing the potential to redefine, and re-appropriate the concept of statebuilding in the field of peace and conflict studies, grounding it in its sociological origins and state formation debates. That means analysing the state not simply as governmental institutions, but understanding it as a complex, interrelated socio-political system. It means moving beyond the false certainty of state capacity discussions towards more complex, and difficult, discussions around societal cohesion. If it is undoubtedly true that some key texts of state formation are Eurocentric in nature and tend to focus on the administrative reach of the state apparatus, or its monopolization of violence and taxation (see for instance Tilly 1990), most of the key sociological texts demonstrate nuanced understandings of the socio-political process of the emergence and evolution of statehood, and have turned their gaze beyond the 'liberal West' to support their arguments (see for instance Badie 2000; Bayart 2009; Migdal 2001). That would imply connecting statebuilding with the wider state formation tradition, understood as 'an historical process whose outcome is a largely unconscious and contradictory process of conflicts, negotiations and compromises between diverse groups whose self-serving actions and trade-offs constitute the "vulgarisation" of power' (Berman and Lonsdale 1992, p. 5).

It is also important to highlight that practitioners have 'rediscovered' the importance of societal cohesion and legitimacy through 'lessons learned' from past failures, especially in the wake of Afghanistan and Iraq. The Petraeus doctrine (or Field Manual 3-24) is a good case in point, even if the innovative framework on legitimacy and winning hearts and minds is fundamentally Weberian and actually represents 'an unacknowledged commitment to an Americanised liberal order' (Cromartie 2012, p. 94). The Human Terrain System deployed by the American Army in Iraq, employing anthropologists to support the army on the ground, is another example of this change of paradigm (again with controversial results). 'Localized' counterinsurgent warfare and statebuilding ('small footprint' interventions) increasingly mesh together, producing surprising results (see Chapter 15 by Louise Wiuff Moe in this volume). It is up to researchers to analyse the results of the new forms of interventions and statebuilding that are occurring around the world. 


\section{STATEBUILDING, PEACEBUILDING, AND OTHER AFFILIATED CONCEPTS}

Peacebuilding has appeared in mainstream policy debates since former United Nations Secretary-General Boutros Boutros-Ghali's 'An Agenda for Peace', where he defined the concept as 'to identify and support structures that will tend to strengthen and solidify peace in order to avoid a relapse into conflict' (Boutros-Ghali 1992, para. 46). It connotes activities that go beyond crisis intervention, such as longer-term development, and the building of governance structures and institutions. The connection between peace and governance is clearer in subsequent academic definitions of the concept, as for instance in Charles T. Call and Elizabeth Cousens' (2008, p. 4) definition of peacebuilding as 'actions undertaken by international or national actors to institutionalize peace, understood as the absence of armed conflict and a modicum of participatory politics'. In contrast, statebuilding is understood as 'actions undertaken by international or national actors to establish, reform, or strengthen the institutions of the state which may or may not contribute to peacebuilding'. For others, statebuilding seems to be an activity included in the larger peacebuilding process. Eva Bertram (1995, p. 392) defined peacebuilding missions as sharing most, if not all, of the following characteristics: (1) they deal with conflicts within rather than between states; (2) the host government is one of the parties to the conflict; (3) their aim is to develop and or implement a political transition following or accompanying an end to military hostilities; and (4) a central component is the reform or establishment of basic state institutions.

In reality, there is indeed 'as many visions of peacebuilding as there are experts on the issue and actors on the field' (David 1999, p. 27). However, it appears that the distinction between statebuilding and peacebuilding relies on one central claim: that peacebuilding is a wider, more comprehensive enterprise than statebuilding, which is in turn defined as a technical and institutional set of practices. Hence, the distinction relies on adopting - without challenging - the neo-Weberian understanding of the state and statebuilding. The institutional approach is taken as a given, even when scholars engage critically with the concept. Compounded with this issue, understanding peacebuilding as 'building a broad peace framework' renders the term useless analytically, making it too vague to be helpful. It seems more fruitful to follow actors in their daily interaction on the ground, rather than artificially separating activities on the premise of their mandate or intended goals (Lemay-Hébert 2017).

Furthermore, this artificial conceptual separation does not come without repercussions (for more on the contested process of knowledge production, see Chapter 3 by Berit Bliesemann de Guevara and Roland Kostić in this volume). To give another example, the artificial separation between statebuilding and nationbuilding - a separation that is particularly present in the American literature on the subject ${ }^{1}$ - contributes to legitimizing statebuilding interventions on the basis that they are apolitical, technical activities, compared to the more controversial, and deeply political, nationbuilding process (Lemay-Hébert 2009). Hence, nationbuilding is defined by Call and Cousens (2008, p. 4) as 'actions undertaken, usually by national actors, to forge a sense of common nationhood, usually in order to overcome ethnic, sectarian, or communal differences; usually to counter alternate sources of identity and loyalty; and usually to mobilize a population behind a parallel state building project'. Most authors simply dis- 
tinguish state and nationbuilding along the lines of international involvement: statebuilding would 'only' restructure the institutions of the state, while nationbuilding would be a more thorough process of identity reconstruction.

However, this type of analysis encourages the belief that one can engage with the state (statebuilding) without engaging the nation (nationbuilding). For example, Marina Ottaway (2009) asserts that the goal of statebuilding interventions 'should not be to impose common identities on deeply divided peoples but to organize states that can administer their territories and allow people to live together despite differences'. According to this point of view, it seems possible to 'organize states' while leaving the 'identities' of their populations intact. This semantic distinction in effect enables practitioners to legitimize interventions on the basis that they are apolitical, technocratic endeavours, in contrast with nationbuilding which is seen as attempts to redefine the identity of communities subject to the interventions. If the semantic distinction between state- and nationbuilding can be made in theory, it is a rather difficult, even impossible, distinction to observe in practice. Every statebuilding programme, however technical and apolitical they may appear to be, will have ramifications beyond the actors' intended outcomes. 'Nationbuilding' is not something that simply happens through high-politics and at 'critical junctures' in history; as Ernest Rennan famously said, the nation is the plebiscite of the everyday (1997) [1882]. Everyday politics of statebuilding will have repercussions in the 'nationbuilding' sphere of local politics (see also Chapter 13 by Janosch Neil Kullenberg in this volume). The same logic can apply to the distinction between peacebuilding and statebuilding, where statebuilding is bound to impact the nature of the 'peace' on the ground.

\section{EDITORIAL VISION AND ORGANIZATION OF THIS VOLUME}

A few rationales have guided the editing process of this Handbook. First, we have consciously adopted a more conceptual or analytical angle in regard to the literature, shedding light on recent debates in the field of intervention and statebuilding and using specific examples to support the arguments rather than just focusing on case studies. This is partly due to space constraints, but also because we wanted to make sure that this Handbook will remain topical in the future. Only time will tell if this editorial approach was the right one. Having said that, and without losing the analytical edge, some chapters are more empirical than others (see Chapter 31 by Chilmeran and True, Chapter 16 by Martin-Mazé and Chapter 15 by Wiuff Moe). Second, the Handbook adopted a gender parity approach, with a commitment to an equal number of female and male contributors; we ended up with twice as many female contributors as male contributors, which is a clear signal that there is no reason to keep perpetuating the marginalization of female scholars in edited books and Handbooks. Finally, the Handbook presents a mix of established scholars and early career researchers, identified as rising stars in the field.

Taken as a whole, a number of themes emerge in this Handbook. First, and following the spirit of moving beyond the current orthodoxy as pointed out in this chapter, the Handbook is grounded in critical studies and highlights a number of research avenues and debates which could help readers enrich their own regional interest or fieldwork. Linked to this consideration, the conditions for the production of knowledge on intervention and statebuilding practices is one of the key themes of this Handbook. In Chapter 2, David Chandler questions practices of 
intervention and statebuilding in a context where non-linear and emergent causality is increasingly recognized by policy actors, noticing a shift in policy circles towards richer, 'posthuman', understanding of knowledge generation. Berit Bliesemann de Guevara and Roland Kostić, in Chapter 3, explore the production and diffusion of knowledge, analysing the different strands within knowledge-focused studies in intervention and statebuilding, and in Chapter 4, Elisa Randazzo explores the limits of engaging with indigenous knowledge following the 'relational turn'. In Chapter 5, Isabel Rocha de Siqueira also looks at knowledge production and data production, this time analysing quantification itself as the way of performing politics and how it limits the spectrum of possibilities for actors. Finally, Florian P. Kühn in Chapter 6 suggests to take ambiguity seriously. He argues that it allows giving credit to the multiple truths at work in politics revolving around statehood, violence, legal governance, and notions of progress.

Another common theme explored in this Handbook is the crisis of confidence in interventionary dynamics. Chapter 7, by Shahar Hameiri and Fabio Scarpello, starts from the consensual premise - at least in this Handbook - that international interventions have failed to achieve many of their objectives, and argue that a neglected, though crucial, dimension of the struggles shaping intervention outcomes is the politics of scale. Chapter 8 by Pol Bargués-Pedreny and Xavier Mathieu analyses the current miasma of despair regarding international interventions as the result of three successive errors: silencing, problematizing and stigmatizing cultural difference. This enables the authors to suggest three new starting points: approaching difference as multidimensional, refusing to essentialize difference, and focusing on the power relations that make difference exist in the first place. In Chapter 9, Philipp Lottholz highlights how post-colonial scholarship has foregrounded enriching analyses of intervention and statebuilding, which have also helped to transcend the self-contradictions and impasse of the debate around critical approaches to statebuilding. Finally, despite the patchy record of interventions supporting democratization, Sonja Grimm in Chapter 10 argues that democratic rule is nevertheless the only legitimate option for the conflicting factions - as far as it offers an institutional solution to violent conflicts based on the participation of all relevant factions.

There is also a willingness to move beyond the restrictive understanding of statebuilding, connecting with wider sociological understandings of state formation for instance. In Chapter 11, Outi Donovan argues for the need to understand the parallel, disruptive practices that directly challenge the international statebuilding project, and she offers to use the 'contentious politics' lens (borrowed from sociology of state formation and popularized by Charles Tilly and Sidney Tarrow among others) to understand how domestic statebuilding actors negotiate the shape and form of the process. Volker Boege, in Chapter 12, also looks at state formation, this time through the lens of hybridity, whereas Janosch Neil Kullenberg looks at everyday politics of intervention in Chapter 13, analysing how practices and habits shape intervention from the bottom up. Claire Mcloughlin, in Chapter 14, looks at the interplay between state legitimacy and service provision by non-state actors, calling for a more nuanced understanding of the 'non-state' category. Louise Wiuff Moe in Chapter 15 looks at practices re-making and decentring sovereignty, which contribute to new localized processes of self-styled state formation, and Médéric Martin-Mazé in Chapter 16 opens up new research avenues by analysing the 'social field' where interventions are carried out, located in the blind spot of the opposition between global experts and local brokers.

Other crosscutting themes include how international justice is connected with intervention and statebuilding. Sara Dezalay, in Chapter 17, proposes a political sociology of international justice to trace the significance of international norms and international justice institutions in 
global and domestic politics, whereas Catherine Baker and Jelena Obradovic-Wochnik look at the convergences and divergence between transitional justice and peacebuilding in Chapter 18, and Cecilia Jacob looks at the development of international laws and norms for the protection of civilians in contexts of military intervention in Chapter 19.

There is also a focus on spatial and temporal dimensions of intervention and statebuilding in the Handbook. Annika Björkdahl and Stefanie Kappler in Chapter 20 look at statebuilding as a spatial process, understanding the emergence of new states as a process that emerges from processes of place-making and space-making, whereas Róisín Read and Roger Mac Ginty in Chapter 21 analyse intervention discourses and practices through the notion of temporality.

There is also an interesting discussion recording the power of narratives to understand interventions and statebuilding. Josefin Graef and Raquel da Silva in Chapter 22 provide an overview of the uses of narrative in the field to date, highlighting its value for understanding power imbalances, the complexity of human experiences and knowledge creation, and ethical challenges connected to fieldwork. Berit Bliesemann de Guevara and Catherine Goetze in Chapter 23 argue that myth concepts are useful to explore the powerful foundational narratives and commonly held beliefs underpinning international politics. Myths have the effect of imposing and maintaining an already dominant social order in the international system, but they also allow narratives of change to develop.

There are also a number of chapters on technological advances in interventions, and how this impacts the field of intervention and statebuilding. In Chapter 24, Kristan Stoddart looks at the landscape of cyberspace in the areas of statehood and intervention; in Chapter 25, Astri Suhrke analyses the use of armed drones in interventions; and in Chapter 26, Katja Lindskov Jacobsen traces the scope and development of humanitarian refugee biometrics.

Another theme that emerges in the Handbook is the logics of securitization practices of international interventions. In Chapter 27, Lorraine Elliott analyses transnational environmental crimes and offers a critique of strategies of intervention against transnational criminality that seek to replicate the practices of strong states in an orthodox Weberian sense. In Chapter 28 , Florian Weigand argues that bunkerization and fortification in statebuilding processes is at odds with basic values and goals of statebuilding, peacebuilding and the delivery of humanitarian aid. In Chapter 15, as previously mentioned, Louise Wiuff Moe also contributes to widening the debate around the concepts of securitization and stabilization, and Astri Suhrke in Chapter 25 connects the use of drones with human security discussions.

The Handbook also includes a number of excellent chapters on feminist research applied to intervention and statebuilding. Maria O'Reilly in Chapter 29 examines the crucial insights that are gained by bringing women, gender, and feminism into research. Nina Wilén, in Chapter 30 , tries to understand why security sector reform fails to meaningfully engage with gendered considerations, and argues that it fails because a broader participation which takes into account the voices of the marginalized is not envisioned. Ultimately, for Wilén, this means that security sector reform (SSR) remains a conversation by, and for, men; an insight, I would say, that can be expanded beyond SSR to the wider field of intervention. Focusing particularly on the case of Iraq, Yasmin Chilmeran and Jacqui True, in Chapter 31, apply a feminist political economy framework to examine women's experiences of gender-based violence and structural violence.

The end result offers a glimpse into the key debates that structure the field of intervention and statebuilding, and peace and conflict more widely. I hope that readers will subsequently seize the opportunity to deepen some of these debates and analytical discussions covered in this Handbook. 


\section{ACKNOWLEDGEMENTS}

I would like to thank Edward Elgar's editorial director, Alex Pettifer, as well as Daniel Mather for their support in producing this Handbook. I would also like to thank the contributors to the Handbook, who have managed to turn this enterprise into a very interesting and thought-provoking project. I would like to thank Rob Skinner and Joseph McKay for their useful suggestions for this chapter, as well as Mary-Louise Hickey for the copy-editing assistance provided.

\section{REFERENCES}

Badie, B. (2000), The Imported State: The Westernization of the Political Order, Stanford, CA: Stanford University Press.

Bayart, J.-F. (2009), The State in Africa: The Politics of the Belly, 2nd edn, London: Polity Press.

Berman, B. and J. Lonsdale (1992), Unhappy Valley: Conflict in Kenya and Africa. Book One: State and Class, London: James Currey.

Bertram, E. (1995), 'Reinventing governments: The promise and perils of United Nations peace building', Journal of Conflict Resolution, 39 (3), 387-418.

Boutros-Ghali, B. (1992), 'An agenda for peace: Preventive diplomacy, peacemaking and peace-keeping: Report of the Secretary-General', A/47/277-S/24/111, 17 June.

Call, C. T. and E. M. Cousens (2008), 'Ending wars and building peace: International responses to war-torn societies', International Studies Perspectives, 9 (1), 1-21.

Cromartie, A. (2012), 'Field manual 3-24 and the heritage of counterinsurgency theory', Millennium: Journal of International Studies, 41 (1), 91-111.

David, C.-P. (1999), 'Does peacebuilding build peace? Liberal (mis)steps in the peace process', Security Dialogue, 30 (1), 25-41.

Giddens, A. (1985), The Nation-State and Violence, Cambridge: Polity Press.

Lemay-Hébert, N. (2009), 'Statebuilding without nation-building? Legitimacy, state failure and the limits of the institutionalist approach', Journal of Intervention and Statebuilding, 3 (1), 21-45.

Lemay-Hébert, N. (2013), 'Rethinking Weberian approaches to statebuilding', in D. Chandler and T. D. Sisk (eds), The Routledge Handbook of International Statebuilding, Abingdon: Routledge, pp. 3-14.

Lemay-Hébert, N. (2014), 'The semantics of statebuilding and nationbuilding: Looking beyond Neo-Weberian approaches', in N. Lemay-Hébert, N. Onuf, V. Rakić and P. Bojanić (eds), Semantics of Statebuilding: Language, Meanings and Sovereignty, Abingdon: Routledge, pp. 89-105.

Lemay-Hébert, N. (2017), 'Exploring the effective authority of international administrations from the League of Nations to the United Nations', Journal of Intervention and Statebuilding, 11 (4), 468-89.

Lemay-Hébert, N. (2019), 'State fragility and international recognition', in G. Visoka, J. Doyle and E. Newman (eds), Routledge Handbook of State Recognition, London: Routledge, forthcoming.

Lemay-Hébert, N. (2020), 'Peace, intervention and state fragility', in G. Visoka and O. Richmond (eds), Oxford Handbook of Peacebuilding, Statebuilding and Peace Formation, Oxford: Oxford University Press, forthcoming.

Lottholz, P. and N. Lemay-Hébert (2016), 'Re-reading Weber, re-conceptualizing state-building: From neo-Weberian to post-Weberian approaches to state, legitimacy, and state-building', Cambridge Review of International Affairs, 29 (4), 1467-85.

Migdal, J. S. (2001), State in Society: Studying How States and Societies Transform and Constitute One Another, Cambridge: Cambridge University Press.

Ottaway, M. (2009), 'Think again: Nation-building', Foreign Policy, 9 November, https://foreignpolicy .com/2009/11/09/think-again-nation-building/ (accessed 12 July 2019).

Rennan, E. (1997 [1882]), Qu'est-ce qu'une nation?, Paris: Mille et une nuit.

Richmond, O. P. (2014), Failed Statebuilding: Intervention, the State, and the Dynamics of Peace Formation, New Haven, CT: Yale University Press.

Smith, D. (2018), 'Introduction: International stability and human security in 2017', in SIPRI, SIPRI Yearbook 2018: Armaments, Disarmament and International Security, Stockholm: Stockholm International Peace Research Institute, pp. 3-23.

Tilly, C. (1990), Coercion, Capital and European States: AD 990-1990, Cambridge, MA: Blackwell. 
Weber, M. (1948), 'Politics as a vocation', in H. H. Gerth and C. W. Mills (eds and transl.), From Max Weber: Essays in Sociology, New York: Oxford University Press, pp. 77-128.

Zuercher, C. (2006), 'Is more better? Evaluating external-led state building after 1989', CDDRL Working Paper no. 54, Stanford, CA: Center on Democracy, Development and the Rule of Law, Stanford University, April. 